\title{
Ethics in Business: Practices by the Street Hawkers’
}

\author{
Muhammad Sabbir Rahman (Corresponding author) \\ Senior Lecturer, Graduate School of Management, Multimedia University, Cyberjaya \\ Persiaran Multimedia, 63100 Cyberjaya, Selangor Darul Ehsan, Malaysia \\ E-mail: sabbiriiu@gmail.com
}

Md. Mahmudul Haque \& Abdul Highe Khan

Graduate Research Assistant, Faculty of Economics and Management Science

International Islamic University Malaysia

E-mail: tasnim128@yahoo.com,khaniium@yahoo.com

Masum Murtaza

Senior Lecturer, School of Business

Department of Business Administration

Northern University, Bangladesh

Received: Dec. 1, 2012

Accepted: December 17, 2012 Published: January 1, 2013

doi:10.5296/jmr.v5i1.2785

URL: http://dx.doi.org/10.5296/jmr.v5i1.2785

\begin{abstract}
Street markets are one of the most exciting trends in Malaysia's act as an alternative for small-time traders to sell their goods in the evenings. This paper examines the factors behind the unethical business practices by the street hawkers in Malaysia. The research methodology adapted in this research with using a descriptive study from the hawkers of various street markets in Kuala Lumpur area in Malaysia where 150 respondents were surveyed under five traders category for instance pirated CD, shoes, vegetables, food, fish and meat. To test the hypothesis this research utilized multiple regressions. The result shows unethical behavior of street hawkers highly influenced by lack of religious foundation followed by their limited income, greediness, personal biases, lack of integrity. Findings derived from this study would enable the reader to understand the types of unethical practices and reason behind the practices by the street hawkers in Malaysia which was previously unexplored under this area.
\end{abstract}

Keywords: Street Market; Unethical Business Practice; Kuala Lumpur 


\section{Introduction}

Hawking constitutes the bulk of informal sector activities in Malaysia. With the turn of the century and changes in the socio-economic environment in Malaysia the context of the street markets business in city has changed over the year. Generally, people in Malaysia, particularly in Kuala Lumpur city are very busy and do not seem to have much time to go far away to a luxurious market to purchase necessary products. This research reaffirms the importance of high standards of business conduct in street markets. Each hawker should apply code of ethics with common sense and the attitude of seeking full compliance with the rules presents in society. It is expected by the consumers that hawkers of the street market must perform their business practices and follow ethical behavior which comply the rules those are issued or modified from time to time. Whatever the reasons though, it is clear that standing firm against unethical temptations has been and will continue to be a test confronting every businessperson involved in large or small enterprises (Cooke, 1988; Stoner, 1989; Werner,1992). This research examine why this unethical behavior have taken place in street markets? To answer this research question few possible explanations and testing were conducted which included with (1) greediness, (2) limited income, (3) a lack of religious foundation (4) personal biases, and (5) Lack of integrity. The main Objective of this research is to investigate the factor that leads to the declining ethical practices in street market in Malaysia.

\section{Literature Review}

A street market is an outdoor market such as traditionally held in a market square in a market town, and are often held only on particular days of the week. Street market was defined by Huang et al, (2009) as a trading place during the evening, where small businesses offered a variety of cheap products and cooked food. Lee et al. (2008) defined Street markets as "street markets operating at street, mainly in urban or suburban areas that generally tend to have more leisure, shopping, and eating areas”. The Street markets offered wide range of foods and non-food items usually operate once or twice a week depending on the popularity of the street markets in a specific place. The traders would sell tropical fruits, vegetables, fish, meat, poultry, dairy product, toys, accessories, clothes, or local jungle exotic plants and food that would be peculiar only to the specific areas that they operated. In Malaysia, street market is based on the concept of open-air shopping, where street hawkers or petty traders occupied a designated part of a street to set up their stalls. The designated street, a normally busy one during the day, would be closed off to traffic from early evening until late at street. The area would be transformed into a network of stalls with multi-colored lights for as far as the eye could see. The street markets reflected a piece of the Malaysian unique culture for they portrayed the eating preferences, interaction patterns and some of the evening leisure activities of the various ethnic groups in the country.

The influence of culture on an individual's ethical perception in street market has been supported by a number of studies. A circumstance where the passion for money subordinates ethical consideration and in most circumstances should be considered unethical. For example Joyner et al. (2002) argued that values, ethics and are not mutually exclusive but are 
interrelated. The literature in street market hawker's ethics is evolving. Earlier studies in the late 80's and early 1990's concerned with entrepreneurship in the street market and ethics examine the ethical attitudes of entrepreneurs regarding problematic behavior as well as more general aspects of ethics applied to the street market (Teal and Carroll, 1999, Ackoff, 1987, Brenkert, 1999, McGrath, 1999, Barringer, 1997; Cornwall, 1998, Sciarelli, 1999). Increasingly, researchers are beginning to examine ethics and entrepreneurship in street marketing greater detail. With regard to the study of ethics in street market, Chau and Siu (2000) presented the only published paper in this area.

\subsection{Greediness}

Sciarelli (1999) mentioned that a person's reputation eventually catches up with them limiting business opportunities. In greed, the greedy person sometimes is only in business for the money and the enjoyment of lying and getting away with it. Greediness is one of the anticipants of unethical behavior. Any person who has greed in his or her mind, he or she would attempt to do unethical behavior at any profession. Scholars like Aristotle, Plato reasoned that greediness is the negative side of human character and it influence human being to do unethical behavior in their daily life, professional life (Shklar, 1990; Wang and Murnighan, 2011). Aquino et al. (2009) and Gino and Pierce (2009) examined that human being is very interested about financial gain and to gain financial benefits they go for unethical behavior. It was found in research that if anyone holds greed in their mind then it motivates to violate morale principal and do unethical activities to gain self-interest (Steinel and Dreu, 2004). Wimbush et al. (1997) mentioned that, if one person has high self-interest then there has a chance to do unethical behavior. According to Tang and Chiu (2003), managers in Hong Kong who has high love or interest on money intended to do unethical practice to gain desired money. In this research, it will examine how greediness can influence to practice unethical behavior by hawkers in street market.

\subsection{Limited Income}

Income of the people influences both ethically and unethically. Based on the research in China, Lam and Hung (2005) argued that if the income of the people is increasing then most likely people acts more ethical. But Piffa et al. (2012) argued differently that low income people act more ethically then high income people. However, good ethical practices are important in alleviating some of the worst aspects of it. According to Rosalind (2011) examined that the low income businessman has very weak personality in terms of ethics. They also show dispositional attribution. Kraus \& Keltner (2009); Kraus et al. (2010); Grossman and Varnum (2011); Kraus et al. (2011) stated that upper class people are comparatively less ethical. It is not very easy to generalize either of the classes of people are less or high ethical. But based on the result from previous research it can be argued that upper class people of the society are more self-centered compared with lower class people and they are less engaged in social interaction.

\subsection{Lack of Religious foundation}

Ethics is important not only in business but also in all aspects of life as it is one of the 
foundation on which the society is build (Cooke, 1988). A business society that lacks ethical principles is bound to fail sooner or later. According to International Ethical Business Registry, "there has been a dramatic increase in the ethical expectation of businesses and professionals over the past 10 years. Increasingly, customers, clients and employees are deliberately seeking out those who define the basic ground, rules of their operations on a day today”. Huang et al. (2009) mentioned that ethics refers to a code of conduct that guides an individual in dealing with others in street market business. It deals with issues regarding the moral and ethical rights and between a general people and its government, suppliers and dealers. Henry Ford said, "Business that makes noting but money is a poor kind of business". In fact religion plays a significant role for the basic foundation of human being. There is a significant relationship exist among religion, religious knowledge and ethical behavior of human being. Terpstra et al. (1993) found significant relationship between religion and ethics. Similarly Smith and Oakley (1996) established that human being who has strong ethical knowledge, they usually follow more ethics when they go for business. Longenecker et al. (2004) conducted a research on business ethics and religious knowledge. They found that people who has religious knowledge they have more ethical judgment then people who has less religious interaction or knowledge. Lam and Shi (2007) conducted research in Mainland China and Hong Kong and they conclude that Christianity religion has acceptability to establish ethical standards among the people of that region. Wong (2007) conducted another research among Malaysian Christians. The author recommended that Malaysian Christian who follows religious guidelines is more ethically conscious about ethics in business.

\subsection{Personal Biases}

McGrath (1999) explained that empirically the influence of personal and organizational values on marketing professional's ethical behavior. It means that personal and organizational values underlie differences in marketing professional's ethical behavior. The relationship between organizational values and ethical behavior has play a significant factor. However, the same is not the case for the relationship between personal values and ethical behavior.

\subsection{Standards of Integrity}

Czimbal and Brooks (2009) explained that a business success depends on the integrity of its owner and employees. It is known that the severe problems that result in the personal, professional and political area, when anyone, at any level, acts without integrity which is related with ethics. Street market of all types are now taking proactive approach to preventing problems by creating hard rules and regulations about ethics and integrity. It is found that hawkers seemed confused about the differences between ethics and integrity. Barringer, (1997) argued that ethics and integrity in a way people can understand and immediately use. Huang et al. (2009) stated that there is a dynamic relationship between integrity and ethics, where each strengthens, or reinforces, the other. Personal integrity is the foundation for ethics - good business ethics encourages integrity.

\section{Methodology of the Research}

To collect the data this research used convenient sampling procedure on street market 
hawkers in various places of Kuala Lumpur, Malaysia. However, this research utilized convenience sampling over random sampling due to practical reasons. In this study, primary data were collected through distribution of survey questionnaires. Self-structured questionnaire was developed to collect the required primary data from the street market hawkers. The principal component analysis was comprised with 150 respondents. Apart from that demographic information, respondents were also asked to rate their opinion according to seven point rating scale, with a rating seven being "Strongly Agree” and one being "Strongly Disagree”.

\section{Results and Analysis}

The demographic profiles for the data collected are presented in terms of frequency tables. It lists in the information for gender, ages, marital status, number of workers, type of business and frequency they receive information about ethical practice. This survey was conducted in the IIUM street market areas because there are many businessman, suppliers, sellers and consumers of street market which can be seen in IIUM street market.

\subsection{Demographic Profile}

A total of 170 questionnaires were distributed but only 150 were completed. Therefore, this study used 150 respondents response. In this survey, $60 \%$ of the respondents were male while $40 \%$ were female. It can be assumed that males are more active in those places and doing business in street market. Furthermore, $36.6 \%$ of the respondents were among the ages of $36-55$ years, $23.33 \%$ were among the ages of $25-35$ years, and $26.6 \%$ were among the ages 18-24 years, $13.33 \%$ were among the ages 55 and above. Based on the table, the highest rate that can be viewed is $36.6 \%$ among the $36-55$ years old and the lowest is $13.33 \%$ among the 55 above years old. In this sample, $53.4 \%$ of the respondents were married while $46.6 \%$ of the respondents were single. In the street market, usually international hawkers do exist even though local sellers usually take control over the market.

Out of 150 respondents, $40 \%$ were Malay followed by 26.6\% Chinese, 20\% Indian and $13.3 \%$ were international. There level of income were distributed in four category where majority of the respondents were belongs to RM1000 to RM2500 (53.3\%). Among the respondents majority of the hawkers do business in selling vegetables (30\%) followed by shoes (23.33\%), food (20\%), pirated CD (13.33\%), fish and meat (13.33\%). 


\section{Macrothink}

Table 1. Demographic Information of respondents

\begin{tabular}{|c|c|c|c|}
\hline Item & Frequency & Item & Frequency \\
\hline Gender & $\begin{array}{l}\text { Male: } 90 \\
\text { Female: } 60 \\
\text { Total: } 150\end{array}$ & Race & $\begin{array}{l}\text { Malay: } 60 \\
\text { Chinese : } 40 \\
\text { Indian : } 30 \\
\text { International: } 20 \\
\text { Total: } 150\end{array}$ \\
\hline Age & $\begin{array}{l}18-24: 40 \\
25-35: 35 \\
36-55: 55 \\
55 \text { - above : } 20 \\
\text { Total: } 150\end{array}$ & $\begin{array}{ll}\text { Level of } \\
\text { income }\end{array}$ & $\begin{array}{l}\text { Below 1000: } 20 \\
\text { 1000-2500: } 80 \\
\text { 2500-4000: } 40 \\
4000 \text { and above: } 10 \\
\text { Total: } 150\end{array}$ \\
\hline $\begin{array}{l}\text { Marital } \\
\text { status }\end{array}$ & $\begin{array}{l}\text { Single: } 70 \\
\text { Married: } 80 \\
\text { Total: } 150\end{array}$ & $\begin{array}{l}\text { Type of } \\
\text { business }\end{array}$ & $\begin{array}{l}\text { Pirated CD: } 20 \\
\text { Shoe: } 35 \\
\text { Vegetable: } 45 \\
\text { Food: } 30 \\
\text { Fish or Meat: } 20 \\
\text { Total: } 150\end{array}$ \\
\hline
\end{tabular}

\subsection{Reliability Analysis}

Interitem Consistency Reliability is a test of consistency of respondent's answers to all the items in a measure. The most popular test of interitem consistency reliability is the Cronbach's coefficient alpha, which is used for multi point -scaled items. From the table, The Reliability Statistics, we got the Cronbach's Alpha .891, which means that our measuring is very consistent.

Table 2. Reliability Statistics

\begin{tabular}{|c|c|c|}
\hline Cronbach's Alpha & $\begin{array}{c}\text { Cronbach's Alpha Based on } \\
\text { Standardized Items }\end{array}$ & N of Items \\
\hline .891 & .893 & 34 \\
\hline
\end{tabular}

\subsection{Exploratory Factor Analysis}

To assess the dimensionality of the hawker's intention of unethical practices in street market business, factor analysis was performed using the principal factor/component (PF) method, followed by the varimax rotation. Table 3 shows the results of the factor analysis test for the variables. The Kaiser -Meyer-Olkin (KMO) value which is a measure of sampling adequacy, was found to be 0.872 , suggesting that the factor analysis had proceeded correctly and that sample was adequate. The results of the Bartletts Test of Sphericity were also significant, which indicates that the factor analysis processes were correct and suitable for testing multidimensionality. 


\section{Macrothink}

Table 3. KMO and Bartlett's Test.

\begin{tabular}{|l|l|l|}
\hline \multicolumn{2}{|l|}{ Kaiser-Meyer-Olkin Measure of Sampling Adequacy } & .872 \\
\hline Bartlett's Test of Sphericity & Approx. Chi-Square & 360.330 \\
\hline & Df & 91 \\
\hline & Sig. & .000 \\
\hline
\end{tabular}

\subsection{Multiple Regression Analysis}

It is noticed that how much of the variance in the dependent variable (Unethical behavior) is explained by the model (which includes the Greediness, Limited Income, lack of religious foundation, personal biases and lack of Integrity). In this research, the value was .780. Expressed as a percentage, this means in our model explains $78.0 \%$ of the variance in unethical behavior. This tests the null hypothesis that multiple $\mathrm{R}$ in the population equals 0 . The model in this research reaches statistical significance $($ sig. $=.000$; this really means $\mathrm{p}<.0005)$. From the Coefficients Matrix Table the Standardized Beta Coefficients give a measure of the contribution of each variable to the model.

Table 4. Model Summary

\begin{tabular}{|c|c|c|c|c|c|}
\hline Model & $\mathbf{R}$ & R Square & $\begin{array}{r}\text { Adju } \\
\text { Square }\end{array}$ & R & $\begin{array}{l}\text { Std. Error of } \\
\text { the Estimate }\end{array}$ \\
\hline 1 & $.889 a$ & .791 & & .780 & .559 \\
\hline
\end{tabular}

A Predictors: (Constant), Greediness, Limited Income, lack of religious foundation, personal biases and lack standard of Integrity

b Dependent Variable: Unethical behavior

Table 5. Coefficient Matrix.

\begin{tabular}{|lr|l|l|l|l|l|l|}
\hline Model & & $\begin{array}{l}\text { Unstandardized } \\
\text { Coefficients }\end{array}$ & $\begin{array}{l}\text { Standardized } \\
\text { Coefficients }\end{array}$ & $\mathrm{T}$ & \multicolumn{2}{|l|}{ Sig } & \multicolumn{2}{|c|}{ Co.Linearity Statistics } \\
\hline & $\mathrm{B}$ & Std. Error & Beta & & & \multicolumn{2}{|c|}{ Tolerance } \\
\hline 1 (Constant) & -1.151 & .500 & & -2.310 & 0.23 & & \\
\hline Greediness & .319 & .061 & .323 & -5.210 & 0.000 & .588 & 1.701 \\
\hline Limited Income & .369 & .047 & .432 & 7.810 & 0.000 & .728 & 1.373 \\
\hline Lack of Foundation & 775 & .089 & .697 & 8.711 & 0.001 & .347 & 2.880 \\
\hline Personal Biases & .417 & .132 & $\ddots .245$ & 3.162 & 0.002 & .370 & 2.701 \\
\hline $\begin{array}{l}\text { Standard of } \\
\text { Integrity }\end{array}$ & & & .192 & 2.860 & 0.05 & .492 & 2.033 \\
\hline
\end{tabular}

a. Predictors: (Constant), Greediness, Limited Income, lack of foundation, personal biases and standard of Integrity

b. Dependent Variable: Unethical behavior. 
A large value indicates that a unit change in this predictor variable has a large effect on the criterion variable. The $t$ and Sig (p) values give a rough indication of the impact of each predictor variable- a big absolute $t$ value and small $p$ value suggests that a predictor variable is having a large impact on the criterion variable. If the correlation with other variables is high, suggesting the possibility of multi-collinearity. The other value given is the VIF (Variance inflation factor), which is just the inverse of the tolerance value (1 divided by tolerance). VIF values above 10 would be a concern here, indicating multi-collinearity. In this research the tolerance value for all the independent variables is within .728 to .347 which is not even less than .10 therefore, this study will have not violated the multi-collinearity assumption. This is also supported by the VIF values which are less than 10. The next thing to know is which of the variables included in the model contributed to the prediction of the dependent variable. Ignoring any negative signs out the front in this data analysis, it's found that the largest beta coefficient is .697, which is for Lack of Foundation. This means that this variable makes the significant or unique contribution to explaining the dependent variable for unethical behavior, when the variance explained by all other variables in the model is controlled for. The beta values for Greediness (.323); Limited Income (.432); Personal Biases (.245); lack of Integrity (.192), made less of a contribution. The next part this study will discuss the parameters. It is important to know that in multiple regressions the model takes in the form of equation. The equation from the SPSS output gives us the estimates of b- values and these values indicate the individual contribution of each predictor of the model. If it replaces the $\mathrm{b}$ values into equation it is found that it can define the model as in equation. (Y) Unethical behavior $=\mathrm{b} 0+(.323)(\mathrm{X} 1=$ Greediness $)+.432$ (X2= Limited Income) $+.697(X 3=$ Lack of religious Foundation) +.245 (X4= Personal Biases) +.192 (X5= Standard of Integrity). So if put the values into the equation it will be; Unethical behavior = $-1.1511+.323 \mathrm{X} 1+.432 \mathrm{X} 2+.697 \mathrm{X} 3+.245 \mathrm{X} 4+.192 \mathrm{X} 5$.

\section{Conclusion}

This study can be conclude that most of the respondents were not used to behave ethical behavior even they do not know about ethics in business but at least they can define that which is right or wrong. From the findings, it can be inferred that ethical practice in street market is affected by greediness of street hawkers. This was similar to the findings of another study conducted which found that greediness is one of the factor affected to businessman for doing unethical practice in street market business (Bob Czimbal and Michele Brooks, 2009). Furthermore it also inferred that ethical practice in street market is affected by limited income of street hawkers. This was similar to the findings of another study conducted by which found that limited income is one of the factor affected to businessman for doing unethical practice in street market business (Cooke, 1988). From the findings, it also inferred that ethical practice in street market is affected by lack of foundation of respondents. This was similar to the findings of another study conducted by Huang et al. (2009) which found that lack of foundation is one of the factor affected to businessman for doing unethical practice in street market business. Let's close with one last thought on how ethics impacts business; there is probably nothing worse in business than being caught in a lie, particularly by hawkers. Any trust that there may have been before disintegrates immediately and business is lost. In this 
day and age, there is something refreshingly honorable about a person where their word is their bond. Ethics just makes good business sense. Previous studies re-enforce this research findings and corroborate with the literature to suggest that unethical behavior has been seen among street market hawkers when some other factors like greediness, limited income and standard of integrity plays a significant mediating role (Cooke, 1988; Stoner, 1989; Werner, 1992).

\subsection{Managerial implications}

It is been observed that the majority of research into street market hawkers come under the perspective of demographic characteristics (age, gender and income) and their daily life problems. The present study explored the influences of the hawkers perception towards their unethical behavior is depending on greediness, limited income, lack of religious foundation, personal biases and standard of lack integrity plays a role which could contribute valuable output for the street market research. The results obtained from this study allow researchers, academicians and businessman to accept that factors that are influencing by the behavior of hawkers to unethical practices. To serve the multi-racial businessman in Kuala Lumpur city based on this study, businessman can find directions from the research for the improvement of their ethical practices and strategic plan of their business. This study also proposed that hawkers' in street market need to improve their primary knowledge about ethics through massive awareness program.

\subsection{Limitation of the Research}

Researchers faced numerous difficulties to make them understand about the question because of their education level and knowledge about ethics. In fact they were very afraid to give the information. Apparently during the data collection time they were so busy and it was too difficult to take their interview in full scale.

\subsection{Direction of further study}

The study suffers from a number of limitations. Even though the results are interesting and support previous studies, there are some limitations due to the scope of this study in using only hawker's specific area. Hence, the results cannot be easily generalized. This study used convenience sampling procedure which is a limitation and future studies can utilize stratified random sampling procedure with more samples. On the other hand the EFA is difficult to generalize to a larger audience and there was a lack of experimental control for the questionnaire investigation, so the quality of questionnaire cannot be ensured. In addition, further research is needed to measure the behavior and perception of the all type of businesses in working class citizens' from all the major cities in Malaysia.

\section{References}

Ackoff, R. L. (1987). Business ethics and the entrepreneur, Journal of Business Venturing, 2, 185-191. http://dx.doi.org/10.1016/0883-9026(87)90007-3

Aquino K, Freeman D, Reed A, II, Felps W, \& Lim VK. (2009). Testing a social-cognitive model of moral behavior: The interactive influence of situations and moral identity centrality. 
J Pers Soc Psychol, 97, 123-141. http://dx.doi.org/10.1037/a0015406

Barringer, B. R. (1997). The Effects of Relational Channel Exchange on the Small Firm: A Conceptual Framework. Journal of Small Business Management, 35(2), 65-75.

Brenkert, G. (1999). Entrepreneurship, Ethics, and the Good Society', Ruffin Lectures in Business Ethics (Olson Center for Applied Ethics, The Darden School, University of Virginia).

Chau, L, L, F., \& Siu, W. (2000). Ethical decision-making in corporate entrepreneurial organizations. Journal of Business Ethics, 23(4), 365-375. Cooke, R. A.: 1988, Business Ethics: A Perspective (Arthur Anderson and Co., monograph: Chicago).

Czimbal, B., \& Brooks, M. (2009). Ethical Integrity. Booksie.

Gino F, Pierce L. (2009). The abundance effect: Unethical behavior in the presence of wealth. Organ Behav Hum Dec, 109, 142-155.

Grossmann, Igor, \& Varnum, Michael E. W. (2011). Social Class, Culture, and Cognition. Social Psychology and Personality Science, 2(1), 81-89. http://dx.doi.org/10.1177/1948550610377119

Huang, S. O., Liou, Y. H., \& Tzeng, G. H. (2009). Development strategies for improving the service of tourist street markets through hybrid MCDM technique.

Khalilah Zakariya, \& Sue Anne. (2010). Elasticity: rediscovering the street market as an itinerant urban space. The 1st International Conference on Sustainable Architecture \& Urban Design. Issues onglobal energy crisis and its impacts on design, 464-479 proceeding.

Kraus, Michael W., \& Keltner, Dacher. (2009). Signs of Socioeconomic Status: A ThinSlicing Approach. Psychological Science, 20(1), 99-106. http://dx.doi.org/10.1111/j.1467-9280.2008.02251.x

Kraus, Michael W., Cote, Stephane, \& Keltner, Dacher. (2010). Social Class, Contextualism, and Empathic Accuracy. Psychological Science, 21(11), 1716-1723. http://dx.doi.org/10.1177/0956797610387613

Kraus, Michael W., Piff, Paul K., \& Keltner, Dacher. (2011). Social Class as Culture: The Convergence of Resources and Rank in the Social Realm. Current Directions in Psychological Science, 20(4), 246-250. http://dx.doi.org/10.1177/0963721411414654

Lam, K. C., \& Hung, B. W. S. (2005). Ethics, income and religion. Journal of Business Ethics, 61(3), 199-214. http://dx.doi.org/10.1007/s10551-005-0275-4

Lam, K., \& Guicheng Shi,G. (2007). Factors Affecting Ethical Attitudes in Mainland China and Hong Kong. Journal of Business Ethics, 77, 463-79. http://dx.doi.org/10.1007/s10551-007-9360-1

Lee, S-H, Chang S-C, Hou J-S \& Feng C-H. (2008). Street market experience and image of temporary residents and foreign visitors. International Journal of Culture, Tourism and 
Hospitality Research, 2(3), 217-233.

Lee, S-H., Hou, J-S., Heng, S-T., Hou, L-C., \& Lee, C-H. (2005), Street market types and street vendor behavior in Taichung. Journal of Asian Urban Studies, 6(2), 11-24.

Longenecker, J. G., J. A. McKinney, \& C. W. Moore. (2004). Religious Intensity, Evangelical Christianity, and Business Ethics: An Empirical Study, Journal of Business Ethics, 55, 373-386. http://dx.doi.org/10.1007/s10551-004-0990-2

McGrath, R. G. (1999). Falling Forward: Options Reasoningand Entrepreneurial Failure', Academy of Management Review, 24(1), 13-30. http://dx.doi.org/10.2307/259034

Piff, Paul K., Stancato, Daniel M., Cote, Stephane, Mendoza-Denton, Rodolfo, \& Keltner, Dacher. (2012). Higher Social Class Predicts Increased Unethical Behavior. Proceedings of the National Academy of Science, forthcoming. http://dx.doi.org/10.1073/pnas.1118373109

Joiner, T., Pettit, J. W., Walker, R. L., Voelz, Z. R., Cruz, J., Rudd, M. D. (et al). (2002). Perceived burdensomeness and suicidality: Two studies on the suicide notes of those attempting and those completing suicide. Journal of Social \& Clinical Psychology, 21, 531-545. http://dx.doi.org/10.1521/jscp.21.5.531.22624

Piffa, P. K., Stancatoa, D. M., Co^te’́b, S., Mendoza-Dentona, R., \& Keltnera, D. (2012). Higher social class predicts increased unethical behavior. Proceedings of National Academy of Science of the United States of America (PNAS), 109(11), 4086-4091.

Rosalind. D. (2011). Consumer Practices of Low-Income Families with Strategies for Improved Financial Management, Yale-New Haven Teachers Institute.

Serwinek, P. J. (1992). Demographic and Related Differencesin Ethical Views Among Small Businesses. Journal of Business Ethics (July), 555-566. http://dx.doi.org/10.1007/BF00881448

Shklar J. N. (1990). The Faces of Injustice (Yale Univ Press, New Haven, CT).

Smith, P, L., \& Oakley, E, F. (1996). The Value of Ethics Education in Business School Curriculum. College Student Journal, 30, 274-83.

Sciarelli, S. (1999). Corporate Ethics and the Entrepreneurial Theory of Social Success. Business Ethics Quarterly, 9(4), 639-649. http://dx.doi.org/10.2307/3857940

Steinel W., \& De Dreu CKW (2004). Social motives and strategic misrepresentation in social decision making. J Pers Soc Psychol, 86, 419-434. http://dx.doi.org/10.1037/0022-3514.86.3.419

Stoner, C. R. (1989). The Foundation of Business Ethics: Exploring the Relationship between Organization Culture, Moral Values, and Actions. SAM Advance Management Journal, 38-43.

Tang, T. L. P., \& Chen, Y. J. (2008). Intelligence vs. wisdom: Thelove of money, Machiavellianism, and unethical behavior across college major and gender. Journal of Business Ethics, 82(1), 1-26. http://dx.doi.org/10.1007/s10551-007-9559-1 


\section{Macrothink}

Journal of Management Research

ISSN 1941-899X 2013, Vol. 5, No. 1

Tang, T. L. P., \& Chiu, R. K. (2003). Income, money ethic, pay satisfaction, commitment, and unethical behavior: Is the love of money the root of evil for Hong Kong employees? Journal of Business Ethics, 46, 13-30. http://dx.doi.org/10.1023/A:1024731611490

Teal, E. J., \& Carroll, A. B. (1999). Moral Reasoning Skills: Are Entrepreneurs Different?', Journal of Business Ethics, 19(3), 229-241. http://dx.doi.org/10.1023/A:1006037510932

Terpstra, D, E, Rozell, E, E, J., \& Robinson, K. (1993). The Influence of Personalityand Demographic Variables on Ethical Decisions Related to Insider Trading. The Journal of Psychology, 127, 375-89. http://dx.doi.org/10.1080/00223980.1993.9915573

Wang L, \& Murnighan J. K. (2011). On greed. Acad Manage Ann. 5, 279-316. http://dx.doi.org/10.1080/19416520.2011.588822

Werner, S. B. (1992). The Movement for Reforming American Business Ethics: A Twenty-Year Perspective. Journal of Business Ethics, 11, 4-10. http://dx.doi.org/10.1007/BF00871992

Wimbush, J., Shepard, J., \& Markham, S. (1997). An empirical examination of the relationship between ethical climate and ethical behavior from multiple levels of analysis. Journal of Business Ethics, 16, 1705-1716. http://dx.doi.org/10.1023/A:1017952221572

Wong, H, M. (2007). Religiousness, Love of Money, and Ethical Attitudes of Malaysian Evangelical Christians in Business. Journal of Business Ethics, 81,169-91. http://dx.doi.org/10.1007/s10551-007-9487-0

\section{Copyright Disclaimer}

Copyright reserved by the author(s).

This article is an open-access article distributed under the terms and conditions of the Creative Commons Attribution license (http://creativecommons.org/licenses/by/3.0/). 